Canadian University Music Review

Revue de musique des universités canadiennes

\title{
Elaine Keillor, ed. The Canadian Musical Heritage - Le Patrimoine musical canadien. Vol. 6. Piano Music II. Ottawa: Canadian Musical Heritage Society, 1986. 282 pp. ISBN 0-919883-0709
}

\section{Gordana Lazarevich}

Volume 11, numéro 2, 1991

URI : https://id.erudit.org/iderudit/1014201ar

DOI : https://doi.org/10.7202/1014201ar

Aller au sommaire du numéro

Éditeur(s)

Canadian University Music Society / Société de musique des universités canadiennes

ISSN

0710-0353 (imprimé)

2291-2436 (numérique)

Découvrir la revue

Citer ce compte rendu

Lazarevich, G. (1991). Compte rendu de [Elaine Keillor, ed. The Canadian Musical Heritage - Le Patrimoine musical canadien. Vol. 6. Piano Music II. Ottawa: Canadian Musical Heritage Society, 1986. 282 pp. ISBN 0-919883-0709]. Canadian University Music Review / Revue de musique des universités canadiennes, 11(2), 140-142. https://doi.org/10.7202/1014201ar

(c) Canadian University Music Society / Société de musique des universités canadiennes, 1991
Ce document est protégé par la loi sur le droit d'auteur. L'utilisation des services d'Érudit (y compris la reproduction) est assujettie à sa politique d'utilisation que vous pouvez consulter en ligne.

https://apropos.erudit.org/fr/usagers/politique-dutilisation/ 
décennies. Dans la complexité et la diversité du climat culturel présent, il serait téméraire sinon prétentieux d'attendre un impact aussi percutant de Montréal Musiques Actuelles. Souhaitons toutefois que cette manifestation aura laissé une impression d'exploration des possibles et une vision autre de la création musicale, dans toute sa passion et sa générosité.

Jean Piché

ELAINE KEILLOR, ed. The Canadian Musical Heritage - Le Patrimoine musical canadien. Vol.6. Piano Music II. Ottawa: Canadian Musical Heritage Society, 1986. 282 pp. ISBN 0-919883-0709

This sequel to the first volume which appeared in 1983 contains 45 compositions composed between the mid 1880's and 1940. Arranged chronologically by composer's birthdate, the volume includes works by a cross-section of major Canadian composers of the time such as Alexis Contant, W.O. Forsyth, Clarence Lucas, Rodolphe Mathieu, Leo-Pol Morin, and Claude Champagne. Two women - Susie Frances Harrison and Gena Branscombe - are also represented, as are two well known and more contemporary names, Barbara Pentland and John Weinzweig, whose early compositions, Rhapsody (Pentland, 1939) and Dirgeling (Weinzweig, 1939), form part of this collection. The pieces, mainly reprinted in facsimile, are presented in a practical edition designed for use in performance.

The compositions selected for this edition represent a broad spectrum of piano repertoire performed in Canada during the sixty-year period leading up to the Second World War. Mostly they are short salon or parlour pieces intended for in-house performances by amateur musicians. A form of "gebrauchsmusik," or functional music, the repertoire affords a glimpse into the nature of musicmaking in the homes of the educated middle and upper classes.

Some of the pieces such as mazurkas, valses, gavottes, and pavanes originate in the dance idiom. Others are character pieces as exemplified by the selections of the prolific composer W.O. Forsyth. His Wiegenlied (Lullaby), Evening Song (Abendlied), or Henri Gagnon's Deux Pièces de genre extend the tradition of that Romantic piano genre made popular in Europe by Robert Schumann and Edvard Grieg. Descriptive, or programmatic, music is evidenced by such titles as Forsyth's On the Highway, Descriptive Sketch, Op. 40. or Edmund Hardy's To Daffodils, Tone Poem. There are even several fugues and sonatas.

For the most part, the compositions are suffused with sentimentalism, exhibit a 
conservative musical taste, are shallow in content, and present the pianist with only moderate technical challenge. Contant's La Lyre Enchantée and the two valses, for example, are pleasant superficial pieces reminiscent of the bons-bons of Emile Waldteufel. Bryon Tapley's simplistic sonata with its Alberti bass figurations is of dubious quality. Yet, such pieces as Humfrey Anger's Tintamarre, Morceau de salon, Emiliano Renaud's impressionistic A l'Aurore and Claude Champagne's Prélude et Filigrane present the pianist with more challenging repertoire and demand considerable facility at the keyboard.

Not all the pieces are derivative as some clearly present a more individual personal idiom. Mathieu's Trois Préludes of 1921 exhibit greater musical sophistication, while some experimentation with dissonance occurs in Forsyth's Through the Fields (1914), Letondal's Mazurka Sentimentale (1897), and in the selections by Colin McPhee. Within the context of this collection the single selections by Pentland and Weinzweig do not seem to fit. They are each in a very individual style and have so little in common with any of the compositions in this volume that they stand isolated and out of place. They would have been better served in a separate volume of Canadian composers of the 1940s and '50s, as harbingers of new musical directions than to be included with composers whose derivative musical styles are representative of a previous era in Canadian cultural history.

A pioneering edition such as this volume of the Musical Heritage Society series serves several functions: to bring to light little-known works by Canadian composers of the past; to reveal the musical taste of the society for which the pieces were written; and, from the practical point of view, to present today's musicians with new repertoire. One questions, therefore, how representative these pieces are of the composers' general musical style and piano repertoire and what percentage they constituted of the total piano repertoire available to musical amateurs between 1880 and 1940 .

In other words, were Canadian musical amateurs and music lovers as unsophisticated in their musical tastes as these compositions would indicate? How is that aspect of music-making to be reconciled with the Toronto appearances throughout the 1920's of such virtuoso luminaries as Ignaz Friedman, Josef Hoffman, Vladimir Horowitz, and Ignacy Jan Paderewski? An anthology such as this is akin to a history book, and in order to provide today's performer with an understanding of the social implications of these compositions, it would have been appropriate for the editor to have included a bit more information on how the compositions selected for this volume fit into each composer's output for piano and into the general repertoire for the instrument available in Canada at the time. 
One also wonders how representative these pieces are of music actually composed in Canada at the time, considering the large number of expatriates whose works are included in this collection: Branscombe, Tapley, Manning, Lucas, and McPhee.

Editorial interventions in the music are kept to a minimum and are generally restricted to correcting the obvious typographical errors in the original sources. It is surprising, in fact, to see how many errors these early prints contained. A few even eluded the editor of this edition (for example Lucas, p. 73, m. 36, right hand should have a B flat; Forsyth, p. 26, m. 34, beat 1, right hand should have a D natural). Further, in Forsyth's $A$ Song of Summer (p.3 0, m. 8. beat 3, left hand), the nature of the editorial intervention makes it unclear whether the $G$ flat should or should not be considered as a misprint in the original. Considering that a parallel situation in $\mathrm{m}$. 56 in the left hand omits the flat against the $\mathrm{G}$, the implication that the left-hand chord in $\mathrm{m} .8$ is a $\mathrm{C}$ minor rather than a $\mathrm{C}$ diminished chord should have been discussed in the critical notes.

On the whole, this second volume of piano music fulfils the valuable function of contributing to our knowledge of the Canadian musical heritage. It constitutes an important contribution to our overview of a part of our collective cultural experience.

Gordana Lazarevich

LUCIEN POIRIER, ed. The Canadian Musical Heritage - Le Patrimoine musical canadien. Vol. 7. Songs II to French Texts/Chansons II sur des textes français. Ottawa: Canadian Musical Heritage Society, 1987. xlvi, 222 pp. ISBN 0-919883-08-7

The historical and social development of a people is illustrated through its culture; in particular, a nation's song literature highly represents the philosophy and aspirations of that nation because music has the ability to heighten the significance of the meaning of the lyrics. Over the centuries, political movements, labour unrest, national feastdays, heroic endeavours, the outcome of wars, the accomplishments of guilds - all such activities and many more have been celebrated, not just by the braying of trumpets and clashing of cymbals but also through the chanting of congratulatory odes of civic pride by one individual or by multitudes of joyous citizens. Such evidence of humanity's physical accomplishments could be given spiritual support in the public square with the raising of thousands of voices in song or in the private parlour with the quiet 